\title{
Formation of soft-skills in future teachers in the context of teaching practice in a pandemic
}

\section{Treinamento de habilidades suaves para futuros professores no contexto da prática de ensino em uma pandemia}

\section{Formación en habilidades blandas para futuros profesores en el contexto de la práctica docente en una pandemia}

\author{
Oksana Zhukova ${ }^{1}$ (D), Volodymyr Mandragelia² iD, Svitlana Sobolyeva ${ }^{3}$ iD, \\ Tamara Hurenko4 iD, Galyna Hnat ${ }^{5}$ iD
}

\footnotetext{
${ }^{1}$ Karazin Kharkiv National University, Kharkiv, Ukraine.

${ }^{2}$ Bila Tserkva Institute of Continuous Professional Education of State Institution of Higher Education «University of Educational Management» National Academy of Educational Sciences of Ukraine, Bila Tserkva, Ukraine.

${ }^{3}$ Kharkiv National University of the Air Force named after Ivan Kozhedub, Kharkiv, Ukraine.

${ }^{4}$ National university of life and environmental sciences of Ukraine, Kharkiv, Ukraine.

${ }^{5}$ National University "Lviv Polytechnic", Lviv, Ukraine.
}

Corresponding author:

Oksana Zhukova

Email: shtang_an@ukr.net

How to cite: Zhukova, O., Mandragelia, V., Sobolyeva, S., Hurenko, T., \& Hnat, G. (2021). Formation of soft-skills in future teachers in the context of teaching practice in a pandemic. Revista Tempos e Espaços em Educação, 14(33), e16584. http://dx.doi.org/10.20952/revtee.v14i33.16584

\begin{abstract}
Changing the requirements for a modern teacher naturally leads to a change in expected results, targets, approaches and procedures for the development of professional competence of teachers. Innovative transformations of almost all components of the educational system, including the professional training of future specialists, are today the basis for its modernization. The purpose of the study is the peculiarities of formation of soft-skills in future teachers in the context of teaching practice in a pandemic. For this, a number of methods were applied that make up the research methodology, such as systems analysis and synthesis, induction and deduction, comparison, classification, generalization and systematization, idealization and abstraction Professional and pedagogical competence in the field of teaching practice is determined by the totality of the teacher's skills in a special way to structure scientific and practical knowledge in order to effectively solve educational problems. Personal knowledge in this case is the result of developed abilities and orientation, influencing the perception of pedagogical phenomena, situations, as well as ways of transforming them from a scientific standpoint. As a result of the analysis, the main aspects and
\end{abstract}


features of the formation of soft-skills in future teachers in the context of teaching practice in a pandemic were identified.

Keywords: Future teachers. Pedagogy. Skills. Teaching practice. Training.

\section{RESUMO}

Mudar os requisitos para um professor moderno leva naturalmente a uma mudança nos resultados esperados, metas, abordagens e procedimentos para o desenvolvimento da competência profissional dos professores. As transformações inovadoras de quase todos os componentes do sistema educacional, incluindo a formação profissional de futuros especialistas, são hoje a base para sua modernização. O objetivo do estudo são as peculiaridades da formação de soft-skills em futuros professores no contexto da prática docente em uma pandemia. Para tanto, foram aplicados vários métodos que compõem a metodologia de pesquisa, tais como análise e síntese de sistemas, indução e dedução, comparação, classificação, generalização e sistematização, idealização e abstração Determinação da competência profissional e pedagógica no campo da prática docente pela totalidade das competências do professor de forma especial para estruturar o conhecimento científico e prático de forma a resolver eficazmente os problemas educacionais. O conhecimento pessoal, neste caso, é o resultado de habilidades e orientações desenvolvidas, influenciando a percepção de fenômenos pedagógicos, situações, bem como formas de transformá-los do ponto de vista científico. Como resultado da análise, foram identificados os principais aspectos e características da formação de soft-skills em futuros professores no contexto da prática docente em uma pandemia.

Palavras-chave: Competências. Formação. Futuros professores. Pedagogia. Prática docente.

\section{RESUMEN}

Mudar os requisitos para um professor moderno leva naturalmente a uma mudança nos resultados esperados, metas, abordagens e procedimentos para o desenvolvimento da competência profissional dos professores. As transformações inovadoras de quase todos os componentes do sistema educacional, incluindo a formação profissional de futuros especialistas, são hoje a base para sua modernização. O objetivo do estudo são as peculiaridades da formação de soft-skills em futuros professores no contexto da prática docente em uma pandemia. Para tanto, foram aplicados vários métodos que compõem a metodologia de pesquisa, tais como análise e síntese de sistemas, indução e dedução, comparação, classificação, generalização e sistematização, idealização e abstração Determinação da competência profissional e pedagógica no campo da prática docente pela totalidade das competências do professor de forma especial para estruturar o conhecimento científico e prático de forma a resolver eficazmente os problemas educacionais. O conhecimento pessoal, neste caso, é o resultado de habilidades e orientações desenvolvidas, influenciando a percepção de fenômenos pedagógicos, situações, bem como formas de transformá-los do ponto de vista científico. Como resultado da análise, foram identificados os principais aspectos e características da formação de soft-skills em futuros professores no contexto da prática docente em uma pandemia.

Palabras clave: Competências. Formação. Futuros professores. Pedagogia. Prática docente.

\section{INTRODUCTION}

Changing the requirements for a modern teacher naturally leads to a change in expected results, targets, approaches and procedures for the development of professional competence of teachers. Today, in most scientific publications, the main pedagogical meaning of adult education is quite clearly defined, which consists in introducing into education and human consciousness that which did not exist before, as well as supplementing the theory with existing professional and social experience. 
This meaning reflects the essence of adult education, provides a specialist with the opportunity for continuous professional development in accordance with the attitude "education throughout life", and has recently acquired significant social value. However, there are more and more studies that argue that the goal of lifelong education is to create conditions for the growth of a teacher who is able to think and act in conditions of communication and interaction, form his own interpretations and successfully make moral decisions in a situation of rapid change. In the end, the dilemma has not yet been resolved: is adult education the assimilation of new knowledge or the development of a person's existing experience? This issue is especially significant in the field of professional development of teachers; they must be ready for effective interaction between the participants in the educational process. It is clear that such readiness presupposes the teacher's ability to conduct effective communication, master self-organization skills, manage groups of adults and children, and manage emotional states.

Such skills in foreign educational practice are considered as soft skills, which complement hard skills - technical or professional skills. Unlike the latter, which, as a rule, are well measured, fairly stable, identified with specific structures, and are also part of job descriptions and qualifications, soft skills are universal in nature, important for the successful professional and life self-determination of any person regardless of profession. Soft skills are a set of non-specialized, career-critical skills that are responsible for successful participation in the work process, high productivity and are cross-cutting, that is, not related to a specific subject area.

These include the ability to communicate, leadership, diplomacy, the ability to build relationships; skills of team interaction, public speaking, "thinking" skills, the ability to present their ideas, creatively solve non-standard tasks, etc.

Such skills in modern literature are considered as an important component of professional competence, which need constant improvement. Therefore, a teacher educated in a higher educational institution, where traditionally emphasis was placed on the development of tough professional skills, should receive an offer in the field of postgraduate education to actively improve flexible skills in order to be ready to implement educational reforms, to introduce the latest technologies, and to understand their value. conscious creation of subject-subject relations.

Professional and pedagogical competence is a complex education. Its main elements include:

1) competence in the field of theory and methodology of the educational process, in particular, its goals, objectives, principles, patterns, content, means, forms, methods, techniques;

2) competence in the field of professional subjects and knowledge of how to make the learning process, the content of the subject the leading means of educating students;

3) socio-psychological competence in the field of communication processes;

4) differential psychological competence in the field of motivation, abilities, orientation of student youth;

5) autopsychological competence in the field of the merits and demerits of one's own activity and personality. A mature, formed personality is a professional necessity, conditioned by the process of searching for ways to form a pupil's personality. Professionalism of activity is another substructure of the acmeological subspace of the conceptual model, which, as a qualitative characteristic of the subject of activity, is determined by the degree of his mastery of modern content and modern means of solving professional problems.

One of the main components of the "soft skills" of a future teacher is social and communicative competence, which reflects his ability to effectively interact with others, despite changes in the social environment; willingness and ability to contact people of any age; availability of knowledge, skills and abilities of constructive communication; the presence of internal resources necessary to build an effective communicative action in a certain range of situations of pedagogical interaction. Pedagogical interaction is a coordinated activity of a teacher and students, aimed at achieving common educational goals and results and solving important problems. Pedagogical 
interaction itself is an extremely versatile phenomenon, since it contains contact in a dyad (two participants are directly or indirectly involved in the educational process), a triad (and further in ascending order of the number of participants: teacher, student, parents, psychologist, head teacher, etc.), group as an aggregate subject, differing in composition, the nature of the activities performed (student collectives, pedagogical collective, parental committee, the only school collective, etc.); the complex interconnection of social phenomena - the education system, society, social order, and the like.

The emotional component determines the readiness and ability of the future teacher to flexibly manage and manage emotional reactions, both their own and other participants in the educational process, to respond adequately to situations in changing conditions. It is worth noting the importance of emotional intelligence and social facilitation as integral components of the emotional component. Emotional intelligence determines the ability of the future teacher to carry out optimal coordination between his own emotional state and purposeful behavior, and therefore, consists of two vectors: cognitive, aimed at understanding their emotions (reflection), emotions of others (empathy) and behavioral, which is responsible for managing one's own behavior. (selfregulation), behavior of other people (social skills). Today, an attribute of an innovative teacher is reflexivity, which is "a specific way of self-assessment of pedagogical influence, which causes specific changes in the field of knowledge and professional experience of the teacher." It is thanks to the developed emotional intelligence that the teacher is able to correctly understand his own emotions and recognize the emotions and intentions of his students, knows how to manage emotions and change their direction for effective pedagogical interaction. The level of social facilitation in the teacher's professional activity is expressed in the ability to influence at different levels: verbal, non-verbal, paralinguistic. An important role is played by the ability to use speech means, in particular the semantic shades of the synonymous series, stimulate positive bright associations and activate the emotions of schoolchildren. Along the way, we note that when the subjects of the educational process interact, certain difficulties and barriers may arise that the teacher can successfully prevent and overcome, having the social and communicative component of the "soft skills" complex.

The cognitive component in the structure of "soft skills" characterizes a certain level of cognitive flexibility of an individual. These are, in particular, the creative skills of the productive activity of future teachers, the skills of systemic critical thinking (thinking by "results" and "processes"), the ability to search and research activities, to intellectual variation and variability, on the one hand, and stability and constancy, with another; the ability to find, filter and use the information necessary to achieve the goal. Note that the professional activity of a future teacher presupposes a constant creative search, non-standard solutions to various problem situations, the need to go beyond the regulated requirements, will become possible in the context of the entry of a high level of cognitive flexibility.

The professionalism of the activity includes such parameters of the teacher's personality that reflect its operational aspect - the possession of knowledge in action. Therefore, this substructure contains the following components; theoretical and practical preparedness of the educator to work with various categories of student youth. Theoretical readiness precedes practical and provides for the acquisition of subjectively significant knowledge for the teacher, creates not only the image of the projected educational result, but also the image, the conceptual model of the system of means or technologies for achieving the set goal. Practical readiness of a teacher means the formation of his readiness to act in a specific pedagogical situation, applying the means, methods, and techniques of educational activity appropriate to the circumstances. This parameter also includes such components as the skill of the teacher and his technological equipment. The latter are primarily associated with the highlighted stages of educational activity. Each of them requires from the teacher-educator adequate skills in the form of an integral hierarchical system and technology for 
their application, taking into account the assumed and unpredictable educational tasks. The skill of the teacher, combined with possession of modern technologies of research, design, interaction, control, gives him the opportunity to effectively solve the main classes of educational problems. Among them are tasks related to the development of general strategies for educating students, building a system of relations among pupils, social qualities of the individual, designing educational information and means of educational interaction with students, organizing the educational process in the form of a set of educational tasks, evaluating the results of educational activities.

COVID-19 has exacerbated problems of education quality and raised new challenges on the agenda. Among them: readiness of teachers and students for online learning; high speed internet access; the quality and efficiency of assessing the knowledge of schoolchildren and students; organization of entrance and final exams; change in motivation for learning, interaction between parents and students, etc. Added to this are the difficulties of socialization of students, especially younger ones, their acquisition of communication skills, teamwork and much more from the field of soft skills formation. The pandemic affected the content of the educational process in Ukraine against the backdrop of significant economic, socio-political problems, ineffective fight against corruption, and delay in the implementation of important systemic reforms.

\section{METHODOLOGY}

The purpose of the study is the peculiarities of formation of soft-skills in future teachers in the context of teaching practice in a pandemic. For this, a number of methods were applied, which form the research methodology. The study was carried out using the following theoretical methods: systems analysis and synthesis, induction and deduction, comparison, classification, generalization and systematization, idealization and abstraction.

\section{RESULTS AND DISCUSSION}

The teaching profession is one of the oldest. It arose in the early stages of human development in connection with the need to pass on the accumulated experience to the younger generation, later becoming a separate industry. At first, knowledge and skills in using tools, weapons, and the like were to be transferred. For many peoples, these duties relied on the priests, and in ancient Greece, civilian persons - teachers - were engaged in training.

After entering the pandemic phase due to COVID-19 and the ensuing quarantine in most countries of the world, educational institutions began to go online. At the same time, there was a significant differentiation in the closure of educational structures, depending on the degree of development of countries. For example, in the second quarter of $2020,86 \%$ of primary school children actually did not attend school in low human development countries, compared with just $20 \%$ in very high human development countries.

Qualitative changes in the social sphere, profound transformations in the content of the teacher's labor, caused by the socio-economic situation in the country, the introduction of modern technologies of education and training cause continuous changes in professional educational activities. The essential characteristics of the process of professional development of a teacher are determined by the leading role of the development of the student's personality as a future employee, a citizen of an independent state, the unity of the social, philosophical, psychological, pedagogical and physiological nature of the productive work of a teacher. This makes it necessary to conduct this research on the basis of historical, personal, activity, systemic approaches.

The principle of historicism refers to the methodological principles of knowledge. It acts as a way to study pedagogical phenomena in their development. The application of the principle of historicism is especially effective within the framework of a systematic approach, which makes it possible to identify patterns, contradictions, sources of development of educational systems and 
the specifics of the pedagogical activity of a teacher in various political, social, economic and cultural conditions of society at specific historical stages of the formation of society. The method of historical and logical analysis applied by us made it possible to reach the essential characteristics of the educational process and the patterns of professional pedagogical activity (Kryshtanovych, Kotyk, Tiurina, Kovrei, Dzhanda, 2020; Bondarenko, 2021; Shkabarina, 2020).

In pedagogical activity, everything is normative and variable together. The social environment, internal conditions are repeated and changed, educational systems are created and updated in the field of educational work, professional knowledge, skills and abilities are formed. Modern educational technologies are being developed, which at the same time contain positive elements of the experience accumulated by master teachers from different historical eras. So, normativity is the realization of the tendency to preserve all that is useful that is acquired in the activity. On the contrary, variability is the realization of a tendency to change what has been achieved for its purposeful improvement and improvement. Educational activity includes variable algorithms, since it is cyclical in nature. However, these are complex, stochastic algorithms that reflect the variability of the teacher's actions, ensure the development of an individual style of pedagogical activity, innovative means, forms, techniques in working with students.

It is impossible to study educational activities without those problematic situations that directly prompt the teacher to take active action. Such situations are the essence of professional tasks. Professional educational activity in accordance with the teacher requires their professional solution, therefore, the study provides for the selection and analysis of the typology of professional educational tasks. The postulate of analysis and synthesis reflects the two sides of pedagogical activity, its continuous nature. The basis of any theory is a theoretical scheme - a construct in the form of abstract objects, which reflects the foundations and the fundamental essence of the author's position in a particular area of knowledge. The educational activity of a teacher is no exception.

The modern methodology of cognition requires a certain coordinate system - a "systemic basis", which explicates the necessary and sufficient aspects of the mapping of the systemic studied. Such a basis can be constructed based on the materials obtained earlier. The projected basis for the study of individual pedagogical activity can be represented in the form of a multidimensional abstract space, which is being investigated, and the subspaces of which reflect the given activity in terms of methodological worldview positions. This leads to the selection at the first level of the hierarchical structure of three main subspaces: morphology, axiology, praxeology. At the second level, respectively, stand out (Zdanevych, Bielienka, Ponomarenko, Bubin, Tsypliuk, 2021; Stepanko, 2008; Ronkko, Mommo, Aerila, 2016):

(1) the structure, reflects the structure of the investigated activity, needs, values, assessments, development;

(2) functioning, reflecting the dynamics, that is, the praxeological aspect of pedagogical activity, and, accordingly, its cyclical nature.

It is easy to see that the proposed basis as a whole corresponds to those five basic concepts: subject, structure, motivation and function, dynamics and diversity, which are highlighted as a result of a critical analysis of the conceptual system of the psychological theory of activity. Thus, the existing views fit into the proposed theoretical scheme, although they do not exhaust it.

An ambiguous attitude to the problems of upbringing negatively affects the process of professional training of a teacher, in which the tendency of the priority of professional and minority of pedagogical disciplines continues to dominate, although the opposite is proclaimed in words. So, let us note the main fundamental contradictions in the process of training a teacher:

- between the objective requirements of society and subjective difficulties, stereotypical thinking, traditional approaches; 
- between the usual system of teacher training and the individual and creative nature of pedagogical activity;

- between outdated forms, methods, means of teaching pedagogical disciplines and the need for universities, schools to introduce new pedagogical technologies into the educational process that have an educational, stimulating nature.

Table 1. The main problems associated with the use of modern technologies.

No

1

2
Problems

Ineffective development and application of technology in teaching or technicalization of the teaching process (from programmed teaching to the use of information technology computers, computerized information storage systems)

The "technological" approach to the construction of training as a whole, or the technology of training, is ineffective. Our research was carried out within the framework of the second approach. At the center of scientific research is the problem of the effectiveness of education, training of specialists. In recent years, new technologies of intensive, concentrated, problematic, contexts, block-modular training have been formed.

Obtaining the maximum developmental effect of the pedagogical process requires its special technological structure, that is, the creation of an integral didactic system, which would be based on the main provisions of the theory of pedagogical systems. The conceptual model of a professional teacher developed by us makes it possible to create a didactic system, which provides for such objective changes in the personal and activity sphere of the future teacher. First of all, the goals of pedagogical training of students are changing in the direction of strengthening their educational developmental orientation. They, along with the assimilation of universal values and professional knowledge, are guided by deep study, preservation of the spiritual, national treasury, traditions, creative achievements of folk pedagogy, and the folk system of education. And at the same time on - the education of the humane personality of the future teacher. The content of educational training of students in pedagogical disciplines is significantly updated, based on modern theoretical and methodological concepts of the personality-activity direction, national and foreign democratic pedagogical heritage, which makes it possible to use a rich and extremely valuable educational experience. It is assumed that students will become familiar with alternative educational systems, pedagogical innovations (Uliskina, Aginskaya, Karpukhina, 2018; Veeber, Syrjäläinen, Lind, 2015; Richter, 2021; Garber, Hochtritt, Sharma, 2018; Kryshtanovych, Kryshtanovych, Stechkevych, Ivanytska, Huzii, 2020; Kulyk, 2021).

It is well known that the school and university environment influences academic performance through peer influence. Being in the classroom and therefore being able to interact with classmates can have important positive externalities. This impact can occur through different communication channels. Students can teach each other and improve together. High achievement of classmates can motivate a student (through competition or social influence) to work harder,

All experts agree that a carefully designed, planned and flexible education system is a key factor in the development of human capital. Obviously, teaching and learning in educational institutions should be focused on the formation and development of such knowledge and skills that have a perspective and are ahead of the current requirements for specialists of all levels and specializations. Accordingly, there is a certain set of knowledge, skills and abilities that are universal and whose value only grows and actualizes over time. The ability to constantly learn and improve, the inclination to abstract thinking are becoming significant advantages in the world, and are becoming more and more individualized.

The need to form students' soft skills in the process of studying at a higher (professional) school is due to a number of factors, among which a prominent place is occupied by: the changing conditions of the market of services, professions and labor on a global scale; rethinking the role and 
importance of the educational system in the socio-economic development of society, the study of problems associated with labor migration, as well as gender and economic inequality; state policy in the field of financing the higher education system; the capacity of the educational system itself in crisis conditions; different levels of implementation and use of information and communication technologies (digitalization) in economically developed countries and countries with economies in transition; ensuring the quality of personnel training against the background of the changing landscape of the higher education system in Ukraine; the ratio of the cost and quality of educational services; a range of competencies (Hard skills and Soft skills) formed in the learning process, ensuring the demand and competitiveness of higher education graduates in the modern labor market.

We offer a map for the development of soft skills of teachers in teacher development courses, including four blocks:

1. block for the development of communication skills, which provides for the formation and development of the ability to listen and hear; argumentation and persuasion; creating links; team interaction; Negotiation; public speaking; conducting presentations and self-presentation, the ability to quickly establish communicative contact with the interlocutor; understanding possible contradictions between verbal and non-verbal messages; the ability to correctly pose a question, the ability to overcome misunderstandings in communication, for example, at the request to repeat or reformulate, look at or simplify what was said that was incomprehensible.

2. block for the development of personal skills (self-regulation), which provides for the formation and development of awareness and control of one's own emotions and the emotions of others; stress management; managing your own development; planning; time management reflection; use of feedback, empathy.

3. block for the development of effective thinking, which provides for the formation and development of project thinking; ability to think over and make decisions, search and analyze information; creative thinking; logical thinking; strategic thinking.

4. block for the development of activity skills (management), which provides for the formation and development of the ability to motivate, to carry out mentoring; readiness for situational leadership, delegation of authority; project management; providing feedback.

We believe that it would be appropriate to create an environment for finding alternatives, building interaction based on partnership, shared responsibility, "appropriate organization of space, which allows to establish eye contact, interact, communicate; ensuring a balance between content and process; creating diverse connections (with the past, future, other place or time, another area, previous comments of people in the group); creating a space for discussion, where the power of rhetorical persuasion, the "power of argument".

The formation of flexible skills is possible only if the teacher performs different roles, depending on the situation (facilitator, moderator, coach, coach), his open position, based on trust; acceptance of an adult student as an autonomous person; creating a safe psychological space for communication; ability to actively listen, self-reflection; perception of uncertain and risky situations as desirable, as an incentive for self-development; ability to communicative control.

Analyzing the above, we can formulate the conditions for the development of flexible skills in students of advanced training courses:

1. updating the content of the curricula of advanced training courses, which should provide a thorough incorporation into the course preparation of topics that will involve the development of flexible skills;

2. development of author's programs of advanced training courses for the development of soft skills of teachers, which allows teachers to purposefully choose the development of a specific path of self-improvement; 
3. Improving the organization of the educational process aimed at ensuring flexibility, accessibility, continuity of educational programs, which aims to create conditions for the implementation of various trajectories of professional competence, simplify access to educational products using ICT and network resources;

4. expanding the use of innovative technologies in communication courses, aimed at communication, interaction, team building, development of leadership skills;

5. transformation of educational space into coworking, which promotes active participation of teachers in networking in the form of joint educational, research, social projects, as well as academic mobility, which creates conditions for exchange of pedagogical experience, development of new educational programs and technologies, professional competence of teachers .

The conditions for the formation of the declared skills in the conditions of higher education are: the readiness of the teachers themselves to form their own Soft skills competence as a component of professional competence; an interdisciplinary component of the work programs of academic disciplines that are taught in the higher school; improvement by the teacher of techniques and techniques that contribute to increasing the motivation of students to form and develop their skills stated above; expanding the functional-role repertoire and improving the didactic competence of the teacher in the process of forming students' Soft skills; the use of student-centered learning technologies.

\section{CONCLUSION}

Since the inception of the teaching profession, the teacher has been assigned primarily an educational function. A teacher is an educator, a mentor. This is his social, human purpose. Therefore, educational work is a pedagogical activity aimed at solving the problems of all-round harmonious development of the individual by organizing the educational environment and managing various types of pupils' activities. Complication of social production processes.

The development of methods of cognition and the rapid growth of scientific knowledge in society have caused the need for a special transfer of knowledge, skills, and abilities. In this regard, from the field of "pure" upbringing in the pedagogical profession, an independent function has emerged - the educational one. Teaching has become a type of educational activity, mainly aimed at managing the cognitive activity of students. "Education, educating" and "education, teaches" are fused together in a holistic pedagogical process that takes place in the activities of a teacher of any specialty.

Teacher is a holy word. And with this kind word you always remember the teachers who helped you become a human being. Sowers of the reasonable, good and eternal - they talk about teachers. It is always said about an authoritative person (specialist) that she had good teachers and hence the proverb "a tree and a teacher are known by fruit" came from.

An essential feature of pedagogical work is that from beginning to end it is a process of human interaction. This enhances the role of personal relationships in pedagogical work: it emphasizes the importance of moral aspects. The result of pedagogical activity is also specific - a person who has mastered a certain part of social culture is capable of social self-development and fulfillment of certain social roles in society.

In the broad sense of the word, teachers are those who equip the younger generation with knowledge, skills, and abilities. In a narrow sense, the word teacher is a person who has received special training and is engaged in teaching and educating students in an educational institution. This profession is interesting and creative; for a person, she was chosen, she is a source of constant growth and improvement, this is a great work of the soul. 
Authors' Contributions: Zhukova, O.: conception and design, drafting the article, critical review of important intellectual content; Mandragelia, V.: conception and design, drafting the article, critical review of important intellectual content; Sobolyeva, S.: conception and design, drafting the article, critical review of important intellectual content; Hurenko, T.: conception and design, drafting the article, critical review of important intellectual content; Hnat, G.: conception and design, drafting the article, critical review of important intellectual content. All authors have read and approved the final version of the manuscript.

Ethics Approval: Not applicable.

Acknowledgments: Not applicable.

\section{REFERENCES}

Cordeiro, E. de P. B., Marques, M. M. C., \& Costa, M. T. N. (2021). Socio-emotional education: paths to inspire studies, research and practices. Revista Tempos e Espaços em Educação, 14(33), e13729.

https://doi.org/10.20952/revtee.v14i33.13729

Kryshtanovych, M., Kotyk, T., Tiurina, T., Kovrei, D., \& Dzhanda, H. (2020). Pedagogical and Psychological Aspects of the Implementation of Model of the Value Attitude to Health. BRAIN. Broad Research in Artificial Intelligence and Neuroscience, 11(2), 127-138. https://doi.org/10.18662/brain/11.2Sup1/99

Kryshtanovych, M., Kryshtanovych, S., Stechkevych, O., Ivanytska, O., \& Huzii, I. (2020). Prospects for the Development of Inclusive Education using Scientific and Mentoring Methodsunder the Conditions of Post-Pandemic Society. Postmodern Openings, 11(2), 73-88. https://doi.org/10.18662/po/11.2/160

Kryshtanovych, S., Bilyk, O., Shayner, H., Barabash, O., \& Bondarenko, V. (2021). Study of the Experience of the Formation of Professional Competence in Future Managers of Physical Education and Sports. Revista Romaneasca Pentru Educatie Multidimensionala, 13(1), 162-176. https://doi.org/10.18662/rrem/13.1Sup1/390

Kulyk, Y., Kuzmenko, P. ., Tytarenko, O. ., Tsyna, A., \& Khlopov, A. (2021). Professional training of future teachers of labor education and technology by means of information and communication technologies. Laplage in Journal, 7(Extra-C), 538-547. https://doi.org/10.24115/S2446-622020217Extra-C1042p.538-547

Richter, E., Lazarides, R., \& Richter, D. (2021). Four reasons for becoming a teacher educator: A large-scale study on teacher educators' motives and well-being.Teaching and Teacher Education, 102, 103-322

Ronkko, M. L., Mommo, S., \& Aerila, J. A. (2016). The Teachers' Views on the Significance of the Design and Craft Teaching in Finland. Design and Technology Education, 21(2), 49-58.

Shkabarina, M., Melnychuk, L., Koval, V., \& Stupnytska, S. (2020). Formation of Future Educators' Professional Training for Introducing Social Experience by Means of Innovative Technologies of Education to Senior Preschoolers. Behavioral Sciences, 10(2), e42. https://doi.org/10.3390/bs10020042

Stepanko, A. V. (2008). Motivation as a component of readiness of future primary school teachers to work on physical education of schoolchildren. Physical education, sport and culture of health in modern society: collection. Science, 1 , 249-252.

Uliskina, T. K., Aginskaya, N. V., \& Karpukhina, M. A. (2018). The role of the innovative methods, systems and ways in the training of communicative skills in a foreign language. Modern Science, 2, 39-49.

Veeber, E., Syrjäläinen, E., \& Lind, E. (2015). A discussion of the necessity of craft education in the 21st century. Techne serien-Forskning i Slöjdpedagogik och Slöjdvetenskap, 22(1), 15-29.

Zdanevych, L., Bielienka, H., Ponomarenko, T., Bubin, A., \& Tsypliuk, A. (2021). Training technologies as a means of increasing motivation for creative activity of future nursery teachers. Laplage in Journal, 7(Extra-E), 254-261.

https://doi.org/10.24115/S2446-622020217Extra-E1184p.254-261

Received: 19 July 2021 | Accepted: 15 September 2021 | Published: 19 November 2021 